\title{
ZJAWISKO ALKOHOLIZMU W ŚRODOWISKU SZKOLNYM
}

\section{ALCOHOLISM IN THE SCHOOL ENVIRONMENT}

\author{
Magdalena Zaus ${ }^{1}$, Katarzyna Plagens-Rotman², a , Maria Połocka-Molińska, b \\ ${ }^{1}$ Szpital Miejski im. J. Strusia w Poznaniu, Oddział Intensywnej Opieki Medycznej \\ ${ }^{2}$ Państwowa Wyższa Szkoła Zawodowa im. Hipolita Cegielskiego w Gnieźnie \\ ${ }^{a}$ https://orcid.org/0000-0001-7646-7430 \\ ${ }^{\mathrm{b}}$ https://orcid.org/0000-0002-5479-8228
}

DOI: https://doi.org/10.20883/pielpol.2021.12

\section{STRESZCZENIE}

Wstęp. Alkoholizm może dotyczyć każdego człowieka, zarówno starszego, jak i młodszego. Z upływem lat obserwuje się wzrost ilości spożywanego alkoholu przez dzieci i młodzież, coraz łatwiejszy dostęp do niego, jak i obniżenie wieku osób go spożywających. Miejsce, czas, łatwy dostęp do napojów alkoholowych, brak kampanii dotyczącej szkodliwości nadmiernego spożywania alkoholu oraz podejście do tego problemu radia, prasy, telewizji i Internetu - nie pomagają w uświadomieniu młodego pokolenia o skutkach zdrowotnych, społecznych i ekonomicznych. Brak uświadomienia dotyczy też wpływu picia alkoholu na zdrowie fizyczne i psychiczne, przyczyniającego się do przemocy fizycznej (bójki, agresje, napaści) i staje się ogromnym problemem XXI wieku.

Cel. Celem pracy było przybliżenie zjawiska alkoholizmu wśród młodzieży szkolnej.

Materiał i metody. W badaniu wykorzystano metodę sondażu diagnostycznego. Narzędziem badawczym był autorski kwestionariusz ankiety składający się z 37 pytań. Badanymi osobami była młodzież ucząca się w wieku od 17 do 21 lat. Ankiety wypełniło w sumie 130 osób (93 dziewczęta i 37 chłopców).

Wyniki. Średnia wieku badanych wynosiła $18,2 \pm 0,6$ roku (średnia wieku dziewcząt $18,2 \pm 0,5$ roku, a chłopców $-18,4 \pm 0,8$ roku). Powyżej 500 tysięcy mieszkańców mieszkały 43 (33,1\%) osoby, w mieście 100-500 tysięcy mieszkańców - 9 (6,9\%) osób, w mieście 50-100 tysięcy mieszkańców - 18 (13,8\%) osób, a w mieście do 50 tysięcy mieszkańców - 35 (26,9\%) osób. Pozostali byli mieszkańcami wsi - 25 (19,2\%) badanych. Młodzież spożywała alkohol najczęściej: podczas spotkania z grupą znajomych - 113 (86,9\%) osób, przy ognisku, lub na dyskotece - 70 (53,8\%) osób, $w$ barze lub pubie - $62(47,7 \%)$ osoby, na spotkaniach rodzinnych - 55 (42,3\%) osób. Zdecydowana większość młodzieży uważała, że nałogowi alkoholicy powinni być poddani obowiązkowemu leczeniu odwykowemu - 108 (83,1\%) osób. Przeciwnego zdania było $10(7,7 \%)$ badanych.

Wnioski. Należy dążyć, aby wśród młodego społeczeństwa pomagać w kształtowaniu właściwej samooceny i postawy wobec tak wielkiego zagrożenia jakim jest alkoholizm, szczególnie gdy po alkohol sięga młodzież dla poprawy humoru. Zdecydowana większość badanej młodzieży uważa, że nałogowi alkoholicy powinni podlegać obowiązkowemu leczeniu odwykowemu.

\section{ABSTRACT}

Introduction. Alcoholism may affect every person, both young and old. Over the years, we have seen an increase in the amount of alcohol consumed by children and youths coupled with a lowering of the initiation age.

Place, time, easy access to alcoholic beverages, absence of campaigns showing the harm caused by excessive drinking and bad attitudes of radio, television and the Internet do not help making the young generation aware of the health, social and economic consequences. The lack of this awareness also extends to the effect alcohol has on physical and mental health, contributing to physical violence (fights, aggression, assaults) and is becoming a serious problem of the $21^{\text {st }}$ century.

Aim. The aim of the paper was to present the phenomenon of alcoholism among school goers.

Materials and methods. The diagnostic survey method was used in the study. The research tool was a proprietary survey consisting of 37 questions. Respondents were school goers aged between 17 and 21 . The surveys were filled in by a total of 130 persons (93 girls and 37 boys).

Results. The average age of the respondents was $18.2 \pm 0.6$ years (the average age of girls was $18.2 \pm 0.5$ years and boys $18.4 \pm 0.8$ years). Forty-three persons ( $33.1 \%$ ) came from cities with a population exceeding 500,000 inhabitants, $9(6.9 \%)$ from cities with between 100,000 and 500,000 inhabitants, 18 (13.8\%) from towns with a population of $50,000-100,000$ inhabitants and $35(26.9 \%)$ from towns with up to 50,000 inhabitants. The remaining 25 (19.2) came from villages. Young people consumed alcohol most frequently during social meetings with friends - $113(86.9 \%)$, at a bonfire or a discotheque - $70(53.8 \%)$, in a bar or pub $-62(47.7 \%)$, during family meetings $-55(42.3 \%)$. A significant majority of the young people thought that alcoholics should be subjected to compulsory treatment -108 respondents (83.1\%). The opposite view was held by $10(7.7 \%)$ respondents. Conclusions. Efforts are needed to help develop the correct attitude of the young generation towards the threat posed by alcohol and self-assessment, especially in situations where young people use alcohol to improve their mood. A large majority of youth is of the opinion that alcoholics should be treated involuntarily.

KEYWORDS: youth, school, alcohol, addiction. 


\section{Wstęp}

Słowo „alkohol” prawdopodobnie pochodzi od któregoś z dwóch słów arabskich: al-kuhl (antymon, delikatny, drobny proszek) lub al-ghoul (zły duch) [1].

Alkohol był znany człowiekowi od bardzo dawna, wtedy gdy ludzkość zaprzestała koczowniczego trybu życia i zajęła się uprawą ziemi i hodowlą zwierząt. Dlatego uważa się, że jest to najstarszy narkotyk. Pierwsze alkohole powstały przypadkowo na skutek niezamierzonej fermentacji owoców - winogron - oraz jęczmienia. Fermentacji, dodając drożdży, poddawano również ziemniaki. Na skutek działania drożdży dochodzi do zamiany cukru w alkohol. Kiedy poziom fermentacji dobiega końca, drożdże giną i proces produkcji alkoholu zostaje zatrzymany. Destylowany spirytus został odkryty $w X$ wieku przez arabskiego lekarza Phazesa [2].

$\mathrm{Na}$ początku alkohole były wykorzystywane $\mathrm{w}$ celach medycznych, a ich picie wzrastało wraz $z$ ich podażą. Alkohol był środkiem, który wpływał na procesy fizjologiczne organizmu, takie jak: trawienne, działał przeciwbólowo, pomagał na zmęczenie, a także redukował lęk, dodawał sił, energii, odwagi i pewności siebie. Ponadto ułatwiał kontakty między ludźmi. Z czasem zaczął pełnić również funkcje ekonomiczne (zapewniał równowagę rynkową będącą warunkiem stabilności dochodów państwa) [3].

W Polsce jak i w innych krajach europejskich alkoholizm jest sporym zagrożeniem dla społeczeństwa, zarówno starszego jak i młodszego pokolenia. Alkoholizm należy do patologii społecznych, tym bardziej, że picie alkoholu stymuluje nadużywanie narkotyków i innych używek. Obserwuje się ewolucję związaną z obniżającym się wiekiem osób spożywających alkohol. W związku z tym rośnie liczba wypadków komunikacyjnych, ponieważ coraz częściej ludzie młodzi, niedoświadczeni siadają za kierownicą pod wpływem alkoholu. Spożywanie alkoholu skutkuje u nich (u młodzieży szkolnej) relegowaniem ze szkół, wagarowaniem, trudnościami w nauce, problemami rodzinnymi, konfliktami z prawem oraz szkodami w zdrowiu psychicznym i fizycznym. To wszystko wpływa bardzo negatywnie na rozwój młodego pokolenia [4-9].

\section{Cel pracy}

Celem pracy było przybliżenie zjawiska alkoholizmu wśród młodzieży szkolnej.

\section{Materiał i metody}

Badania zostały przeprowadzone, za zgodą dyrektora placówki, wśród 130 uczniów jednej ze szkół ponadpodstawowych w Poznaniu w październiku 2019 roku. Respondentów poinformowano o anonimowości ankiety, o jej tematyce oraz jak należy ją wypełnić.
W niniejszej pracy wykorzystano kwestionariusz ankiety jednokrotnego oraz wielokrotnego wyboru. Chcąc odpowiedzieć na pytanie, jakie są rozmiary zjawiska alkoholizmu w środowisku szkolnym w Poznaniu, przygotowano kwestionariusz ankiety składający się z 37 pytań, w tym pytania określające sytuację społeczno-demograficzną badanego środowiska szkolnego. Pozostałe pytania dotyczyły zjawiska występowania problemu alkoholizmu.

\section{Analizy statystyczne}

Do analizy zależności między zmiennymi jakościowymi posłużono się testem niezależności chi-kwadrat Pearsona, a w przypadku gdy liczebności oczekiwane w tabelach kontyngencji były mniejsze od 5 według wskazań testu niezależności chi-kwadrat z poprawką Yatesa dla tabel o rozmiarze 2x2. Do sprawdzenia różnic dla motywów picia alkoholu między młodzieżą o różnej częstości spożycia alkoholu użyto testu Fp porównującego k częstości.

Za istotną statystycznie przyjęto wartość $p<0,05$. Analizę statystyczną przeprowadzono, korzystając z pakietu statystycznego STATISTICA 10 PL.

\section{Wyniki}

Wiek młodzieży wahał się od 17 do 21 lat. Średnia wieku badanych wynosiła 18,2 $\pm 0,6$ roku (średnia wieku dziewcząt wynosiła 18,2 \pm 0,5 roku, a chłopców - 18,4 $\pm 0,8$ roku). Pozostałe dane socjodemograficzne przedstawiono w tabeli 1.

Tabela 1. Dane socjodemograficzne badanej zbiorowości Table 1. The socio-demographic population surveyed

\begin{tabular}{|c|c|c|c|}
\hline \multicolumn{2}{|r|}{ Parametry/Parameters } & $n$ & $\%$ \\
\hline \multirow{5}{*}{$\begin{array}{l}\text { Wiek } \\
\text { w latach/ } \\
\text { Age in } \\
\text { years }\end{array}$} & 17 & 9 & 6,9 \\
\hline & 18 & 88 & 67,7 \\
\hline & 19 & 30 & 23,8 \\
\hline & 20 & 1 & 0,8 \\
\hline & 21 & 1 & 0,8 \\
\hline \multirow{5}{*}{$\begin{array}{l}\text { Miejsce } \\
\text { zamiesz- } \\
\text { kania/ } \\
\text { Place of } \\
\text { residence }\end{array}$} & Wieś/Village & 25 & 19,2 \\
\hline & $\begin{array}{c}\text { Miasto do } 50 \text { tys. mieszkańców/City up to } \\
50,000 \text { residents }\end{array}$ & 35 & 26,9 \\
\hline & $\begin{array}{l}\text { Miasto 50-100 tys. mieszkańców/City } \\
\text { 50-100 thousand residents }\end{array}$ & 18 & 13,8 \\
\hline & $\begin{array}{l}\text { Miasto } 100-500 \text { tys. mieszkańców/City } \\
100-500 \text { thousand residents }\end{array}$ & 9 & 6.9 \\
\hline & $\begin{array}{l}\text { Miasto powyżej } 500 \text { tys. mieszkańców/ } \\
\text { City over } 500,000 \text { residents }\end{array}$ & 43 & 33,1 \\
\hline \multirow{2}{*}{ Płeć/sex } & Męska/Male & 37 & 28,5 \\
\hline & Żeńska/Female & 93 & 71,5 \\
\hline \multirow{5}{*}{$\begin{array}{l}\text { Sytuacja } \\
\text { materialna/ } \\
\text { Material } \\
\text { situation }\end{array}$} & Bardzo dobra/very good & 32 & 24,6 \\
\hline & Dobra/good & 61 & 46,9 \\
\hline & $\mathrm{Zła} / \mathrm{Bad}$ & 3 & 2,3 \\
\hline & Bardzo zła/very bad & 3 & 2,3 \\
\hline & Trudno powiedzieć/lt's hard to say & 31 & 24 \\
\hline
\end{tabular}

$\mathrm{n}$ - liczba/number, \% - procent/percentage

Źródło: opracowanie własne

Source: author's own analysis 
Aż 98,5\% badanych uczyło się w systemie dziennym, pozostali w systemie wieczorowym stanowiąc tylko $1,5 \%$ badanych. Na pytanie o motywacje wyboru szkoły wskazali, że najczęściej podyktowany był on: własnymi zainteresowaniami - u 87 (66,9\%) osób, zdobyciem zawodu - u 35 (26,9\%) osób, uzyskaniem dobrze płatnej pracy - u 27 (20,8\%) osób, zaspokojeniem ambicji rodziców - u 4 (3,1\%) badanych.

Nieco ponad połowa młodzieży była na utrzymaniu rodziców - 66 (50,8\%) osób. Częściowo zależnych finansowo było $56(43,1 \%)$ badanych. Pozostali byli całkowicie niezależni finansowo - 8 (6,2\%) osób. Na utrzymaniu rodziców było nieco połowa młodzieży - 66 osób stanowiąc $50,8 \%$ badanej społeczności.

$\mathrm{Na}$ pytanie „Dlaczego według Ciebie ludzie piją alkohol?" odpowiedzieli wszyscy badani. Podali oni w sumie 467 odpowiedzi, wskazując od 1 do 8 motywów sięgania po alkohol. Według młodzieży ludzie sięgali po alkohol najczęściej: dla poprawy humoru uważało tak 100 (76,9\%) osób, z powodu zawodów miłosnych - uważały tak 74 (56,9\%) osoby, aby pokonać nieśmiałość - uważało tak 68 (52,3\%) osób, dla szpanu - uważało tak 59 (45,4\%) osób.

Jako inne motywy badani podawali między innymi: „dla towarzystwa”, „rozluźnienie się”, „forma zabawy”, „kłopoty rodzinne, zawodowe, finansowe”, „nieradzenie sobie z problemami”. Szczegółowe dane przedstawiono na rycinie 1.

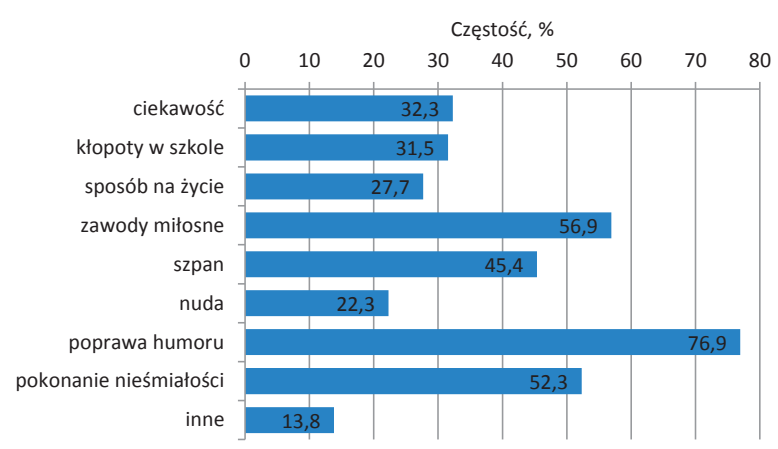

Rycina 1. „Dlaczego według Ciebie ludzie piją alkohol?” Figure 1. "Why do you think people drink alcohol?"

Źródło: opracowanie własne

Source: author's own analysis

Zdecydowana większość młodzieży uważała, że nałogowi alkoholicy powinni być poddani obowiązkowemu leczeniu odwykowemu - 108 (83,1\%) osób. Przeciwnego zdania było 10 (7,7\%) badanych. Pozostali nie mieli zdania na ten temat - $12(9,2 \%)$ osób.

Zdecydowana większość młodzieży uważała, że środki masowego przekazu nie zapobiegają alkoholizmowi - 97 (74,6\%) osób, 8,5\% ankietowanych odpowiedziało, że tak, natomiast $16,9 \%$, że nie ma zdania na ten temat.
Wśród młodzieży, która uważała zabawę bez alkoholu za nudną, największy był odsetek osób mieszkających na wsi (32\% badanych) oraz mieszkających w mieście do 50 tysięcy mieszkańców (31,4\% badanych), a najmniejszy był odsetek osób mieszkających w mieście powyżej 500 tysięcy mieszkańców (2,3\% badanych), $p=0,0014$.

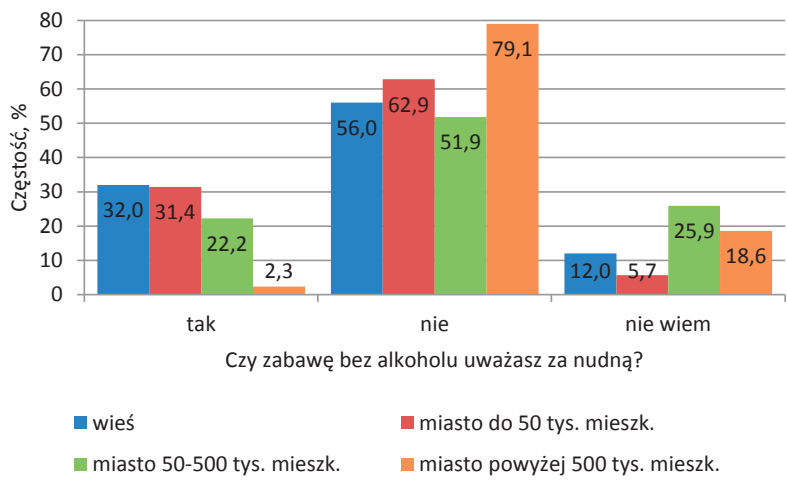

Rycina 2. „Czy zabawę bez alkoholu uważasz za nudną?” w kontekście miejsca zamieszania

Figure 2. "Do you find playing without alcohol boring?" in the context of the place of confusion

Źródło: opracowanie własne

Source: author's own analysis

Wśród młodzieży, która uważała zabawę bez alkoholu za nudną, największy był odsetek osób częściowo zależnych od rodziców (28,6\% badanych), a najmniejszy był odsetek osób całkowicie niezależnych finansowo od rodziców (12,5\% badanych) oraz będących na utrzymaniu rodziców (13,6\% badanych), $p=0,0094$.

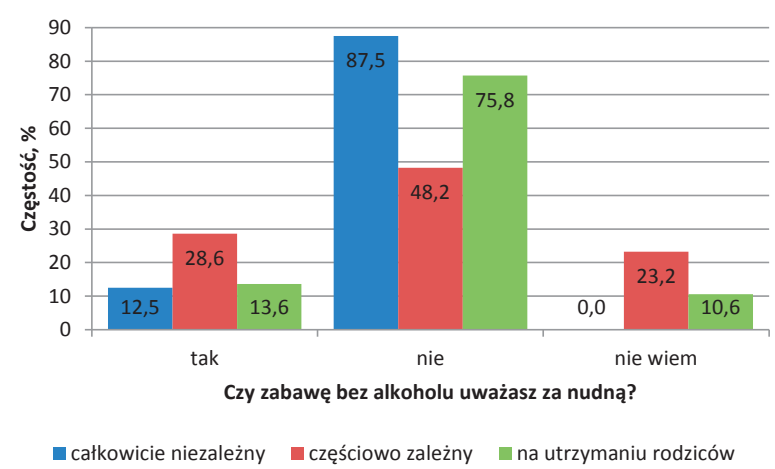

Rycina 3. „Czy zabawę bez alkoholu uważasz za nudną?” w kontekście różnej niezależności finansowej od rodziców

Figure 3. "Do you find playing without alcohol boring?" in the context of different financial independence from parents

Źródło: opracowanie własne

Source: author's own analysis

Wśród młodzieży, która spożywała alkohol kilka razy w tygodniu, największy był odsetek osób całkowicie niezależnych finansowo od rodziców (12,5\% badanych), a najmniejszy osób będących na utrzymaniu rodziców 
(1,5\% badanych), $p=0,0472$. Pozostałe dane przedstawiono na rycinie 4.

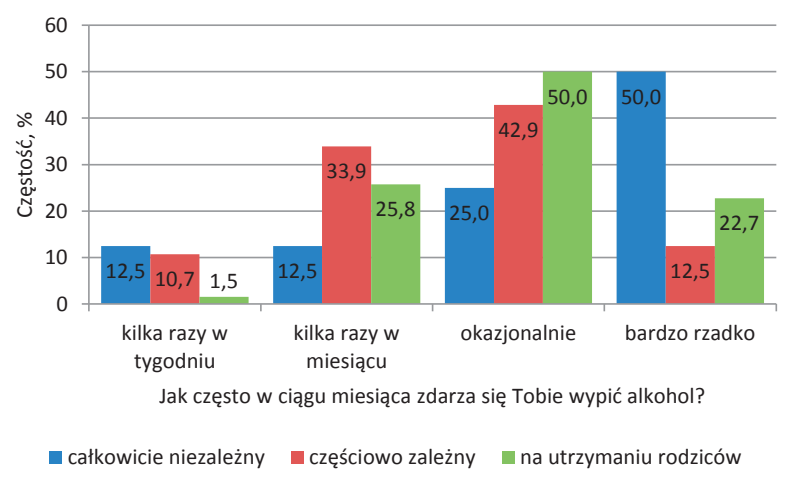

Rycina 4. „Jak często w ciągu miesiąca zdarza się Tobie wypić alkohol?" w kontekście różnej niezależności finansowej od rodziców Figure 4. "How often do you drink alcohol during the month?" in the context of different financial independence from parents

Źródło: opracowanie własne

Source: author's own analysis

Między częstością spożywania alkoholu przez młodzież a motywami picia alkoholu istotne statystycznie różnice wystąpiły tylko dla motywu: sposób na życie ( $p=0,0235$ ). Na motyw „sposób na życie” najczęściej wskazywały osoby spożywające alkohol bardzo rzadko (42,3\% badanych), a najrzadziej - osoby spożywające alkohol kilka razy w miesiącu (10,8\% badanych); poprawa humoru ( $p=0,0065)$. Na motyw „poprawa humoru” najczęściej wskazywały osoby spożywające alkohol kilka razy w miesiącu ( $94,6 \%$ badanych), a najrzadziej - osoby spożywające alkohol bardzo rzadko (61,5\% badanych).

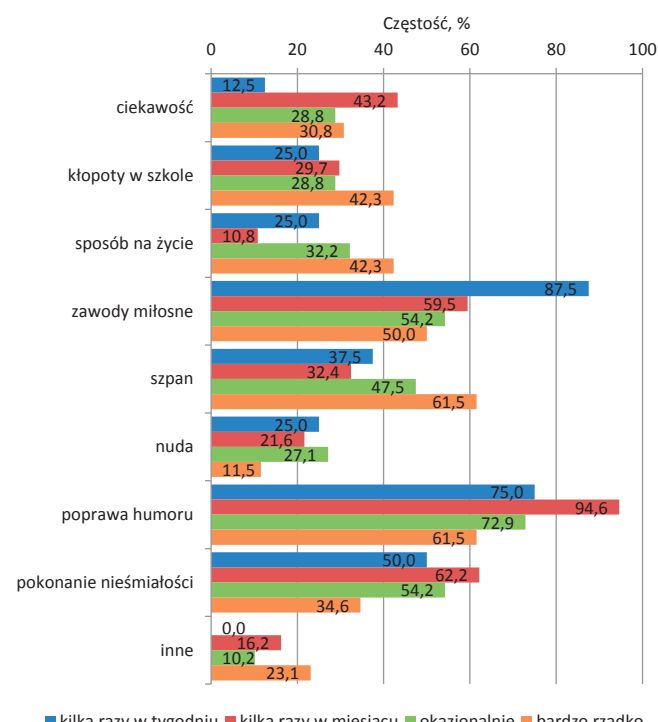

Rycina 5. „Dlaczego według Ciebie ludzie piją alkohol?” Figure 5. "Why do you think people drink alcohol?" Źródło: opracowanie własne Source: author's own analysis

\section{Dyskusja}

Zjawisko alkoholizmu wśród młodzieży szkolnej jest ciągle aktualne. Picie alkoholu wpływa negatywnie na różne sfery życia młodego, kształtującego się i dojrzewającego człowieka. Wpływa na jego stan fizyczny i psychiczny, zdrowie, kondycję i funkcjonowanie w społeczeństwie oraz w grupach rówieśników.

Grupa badanej młodzieży szkolnej była zróżnicowana pod wieloma względami, takimi jak: wiek, płeć, pochodzenie społeczne, miejsce zamieszkania, motywów wyboru szkoły, sytuacji mieszkaniowej, materialnej i finansowej. Badano zarówno dziewczęta jak i chłopców, ich wiek wahał się między siedemnastym a dwudziestym pierwszym rokiem życia. Większość to osiemnastolatkowie, a następnie dziewiętnastolatkowie i siedemnastolatkowie. Młodzież w wieku dwudziestu i dwudziestu jeden lat stanowiły pojedyncze osoby.

Według Chodkiewicza i Juczyńskiego [11] znaczny przyrost liczby pijących obserwuje się między 9. a 10. rokiem życia. Większość badanej młodzieży po raz pierwszy spróbowała alkoholu między 14. a 17. rokiem życia, a najliczniej w wieku 15 lat. Analiza badań własnych wykazała, że wiek badanej młodzieży mieścił się w przedziale od 17 do 21 lat i w tej grupie już obserwowano spożywanie alkoholu. W badanej grupie nie było osób młodszych, tak więc trudno jest odnieść wyniki badań do wcześniejszych publikacji. Biorąc pod uwagę płeć większość badanych to dziewczęta, natomiast analizując miejsce zamieszkania zdecydowana liczba zamieszkuje miasta, pozostali to mieszkańcy wsi.

Mając na uwadze kierunek szkoły, najwięcej osób - 98,5\% uczyło się w systemie dziennym. Jeśli chodzi o motywację wyboru szkoły, to ankietowana młodzież wybierała według własnych zainteresowań - 66,9\%; pozostali kierowali się zainteresowaniem dotyczącym wyboru zawodu - 26,9\%, dobrze płatną pracą - 20,8\%, a pozostali kierowali się chęcią zaspokojenia ambicji rodziców - 3,1\%.

Zdecydowana większość badanych mieszkała razem z rodzicami - 87,7\%, pozostałe to internat, wynajmowany pokój i inne.

Biorąc pod uwagę sytuację materialną badanej młodzieży, można stwierdzić, że grupa w większości miała dobrą sytuację materialną - 46,9\% i bardzo dobrą - 24,6\%. 23,8\% badanych osób nie umiała się określić co do swojej sytuacji materialnej.

Charakteryzując badaną młodzież pod względem zależności finansowej, wykazano, że ponad połowa młodzieży była na utrzymaniu swoich rodziców - 50,8\%. Pozostali byli częściowo albo całkowicie niezależni finansowo.

Na pytanie: „Jak często w ciągu miesiąca zdarza się Tobie wypić alkohol?" - mniej niż połowa respondentów odpowiedziała, że okazjonalnie - 45,4\%. Natomiast $20 \%$, że bardzo rzadko, a 6,2\% kilka razy w tygo- 
dniu. Żaden badany nie spożywał alkoholu „kilka razy w miesiącu". Podobne badania przeprowadzili Nazarko i Bielska [10], w których prawie 1/4 pijących respondentów spożywała alkohol 2 lub 3 razy w miesiącu a 1-2\% codziennie. Najrzadziej pijący $(12,7 \%)$ to ci, którzy pili raz albo dwa razy w miesiącu.

Kolejnym badanym czynnikiem były motywy sięgania po alkohol w opinii młodzieży. W badaniach własnych na pytanie „Dlaczego według Ciebie ludzie piją alkohol?" odpowiedzi udzielili wszyscy badani. Najczęściej po alkohol sięgano dla poprawy humoru (76,9\%), natomiast $56,9 \%$ z powodu zawodów miłosnych, aby pokonać nieśmiałość 52,3\%, a dla „szpanu” 45,4\%. Inne podawane motywy, to: dla towarzystwa, rozluźnienia się, z powodu kłopotów rodzinnych, zawodowych, finansowych oraz nieradzenia sobie z problemami.

Tematem motywu sięgania po alkohol zajęła się również w swoich badaniach Kosek-Nita [11], w których po alkohol sięgano dla ciekawości i dotyczy to $30 \%$ dziewcząt oraz 29\% chłopców. Inne ważne czynniki wpływające na picie alkoholu przez młodzież to chęć zaimponowania, zachęcanie przez dorosłych, możliwość bycia „na luzie”, udawanie bycia dorosłym, rozrywka oraz wzorce rodzinne.

Według badań Nazarko i Bielskiej [10] najpopularniejszym napojem alkoholowym było piwo, a najmniej popularnym wino. Wynika z tego, że piwo być może jest tańsze i dostępniejsze niż lepsze gatunkowo wino.

Innym badanym zagadnieniem mającym swoje miejsce w naukowych pracach są informacje dotyczące odmowy sprzedaży alkoholu osobom nieletnim i nietrzeźwym w opinii młodzieży. Według badań własnych większość młodzieży była świadkiem odmowy sprzedaży alkoholu 64,6\%, pozostałe osoby nie zetknęły się z taką sytuacją. Z odmową sprzedaży alkoholu osobie nietrzeźwej spotkało się - 26,9\% respondentów.

Według badań Nazarko i Bielskiej [10] nieletni mają łatwy dostęp do alkoholu, a 88,5\% ankietowanych nie miało problemów z jego zakupem w sklepach; nieletni obecnie mogą kupić alkohol w punktach sprzedaży zarówno tych legalnych jak i nielegalnych.

Green i wsp. [12] „wskazują, iż częste picie alkohoIu więcej niż 20 razy przed szesnastym rokiem życia wiąże się ze zwiększonym ryzykiem stosowania przemocy fizycznej, a zwłaszcza napaści przez młodych na dorosłych."

W badaniach własnych zdecydowana większość młodzieży stwierdziła, że radio, prasa i telewizja nie zapobiegają piciu alkoholu - 76,4\%. Taka opinia ze strony młodzieży może świadczyć o tym, że obecne działania, programy, kampanie o profilu edukacyjno-profilaktycznym są niezauważalne dla młodzieży lub wywołują niedostateczny efekt. To w konsekwencji może przyczynić się do nieświadomego zwiększenia szkodliwości alkoholu, na organizm młodego człowieka pod względem zdrowia fizycznego i psychicznego.

Wśród czynników, które wykazały istotny związek ze spożywaniem alkoholu w celu urozmaicenia/poprawy zabawy (spotkania towarzyskiego) było zamieszkanie na wsi i mniejszych miastach oraz wsparcie finansowe od rodziców. Być może brak innych rozrywek dla młodzieży i „nadmiar” gotówki stanowi pewne zagrożenie i należy zastanowić się - zwłaszcza opiekunowie osób nieletnich, nad właściwym rozsądnym planowaniem czasu i finansów dla młodego człowieka.

Istotną rolę w częstotliwości spożywania alkoholu miała motywacja: sposób na życie oraz poprawa humoru. Jednak najczęściej taką opcję zaznaczały osoby, które rzadziej spożywały alkohol. Można zatem stwierdzić, że osoby częściej pijące alkohol nie traktują go już jako rozwiązanie, poprawę pewnej sytuacji czy poprawę nastroju. Niepokojący jest również fakt, patrząc na wiek badanej grupy, że istnieje zjawisko spożywania alkoholu dla samego spożywania.

Warto podkreślić, że badania te przedstawiają małą grupę badanych i nie są reprezentatywne, a uzyskane wyniki są oparte na niestandaryzowanych narzędziach badawczych, co może mieć wpływ na ostateczną interpretację uzyskanych danych.

\section{Wnioski}

1. Młodzież sięga po alkohol najczęściej z chęci poprawy humoru.

2. Zdecydowana większość badanej młodzieży uważa, że nałogowi alkoholicy powinni podlegać obowiązkowemu leczeniu odwykowemu.

3. Wśród czynników, które wykazały istotny związek ze spożywaniem alkoholu w celu urozmaicenia/poprawy zabawy, było zamieszkanie na wsi i mniejszych miastach oraz wsparcie finansowe od rodziców.

4. W przypadku osób nieletnich nadużywających alkohol ważną rolę odgrywają rodzice/opiekunowie prawni.

5. Uczniowie uważają, że środki masowego przekazu nie zapobiegają alkoholizmowi.

\section{Piśmiennictwo}

1. Borowski M, Kłosowska E. Alkoholizm jako rodzaj patologii społecznej. Wyd. Naukowe Novum, Płock-Wyszków. 2010.

2. Kinney J, Lepton G. Zrozumieć alkoholizm. PARPA Warszawa 1994.

3. Falewicz JK. ABC problemów alkoholowych. PARPA Warszawa 1994.

4. Jedynak M. Alkoholizm jako zjawisko patologiczne i społecznie destruktywne. [w:] Uzależnienia oraz związane 
z nimi zagrożenia społeczne. Pstrąg D (red). Wyd UR, Rzeszów 2014: 96-117.

5. Van Laere K. Zakłócający wpływ alkoholuna funkcjonowanie granic psychologicznych nastolatka. Remedium 2014, 3: 13.

6. Fudała J. Rozwiązywanie problemów alkoholowych w miejscu pracy. Świat Probl. 2009, 12: 31-33.

7. Foxcroft DR, Lowe G. Adolescent drinking behavior and family socialization factors: a meta-analysis. Journal of Adolescence. 1991; 14(3), 255-273.

8. Sadock BJ, Sadock VA. Concise textbook of child and adolescent psychiatry. Philadelphia: Lippincott Williams and Wilkins, a Wolters Kluwer Business. 2009; 171-176.

9. Latendresse SJ, Rose RJ, Viken RJ, Pulkkinen L, Kaprio J, Dick DM. Parenting mechanisms in links between parents' and adolescents' alcohol use behaviors. Alcoholism: Clinical and Experimental Research. 2008; 32(2): 322-330.

10. Nazarko K, Bielska DE. Picie alkoholu - częste zachowanie ryzykowne młodzieży szkół ponad gimnazjalnych Przegląd Lekarski. 2012; 10: 881.

11. Kosek-Nita B. Problem alkoholizmu wśród młodzieży szkolnej, a możliwości oddziaływań profilaktycznych. Wyd. Uniwersytetu Śląskiego Chowanna Katowice 2000.
12. Green KM, Doherty EE, Zebrak KA, Ensminger ME. Association between adolescent drinking and adult violence: evidence from a longitudinal study of urban African Americans. Journal of Studies of Alcohol and Drugs. 2011; 5: 701-710.

Artykuł przyjęty do redakcji: 08.08.2020.

Artykuł przyjęty do publikacji: 07.07.2021.

Źródło finansowania: Praca nie jest finansowana z żadnego źródła. Konflikt interesów: Autorzy deklarują brak konfliktu interesów

\section{Adres do korespondencji:}

Katarzyna Plagens-Rotman

ul. Ks. Kard. S. Wyszyńskiego 38

62-200 Gniezno

e-mail: plagens.rotman@gmail.com

Państwowa Wyższa Szkoła Zawodowa im. Hipolita Cegielskiego w Gnieźnie 